\title{
Creating a Sustainable Future: Some Philosophical and Educational Considerations for Chemistry Teaching
}

Vilches, A. y Gil Pérez, D. (2013). Creating a Sustainable Future: Some Philosophical and Educational Considerations for Chemistry Teaching, Science \& Education, 22 (7), pp. 1857-1872.

\begin{abstract}
The International Union of Pure and Applied Chemistry (IUPAC) and UNESCO have proposed that the International Year of Chemistry, 2011, should make a strong educational contribution to the goals of the UN Decade of Education for Sustainable Development. This emphasis is absolutely necessary because education for sustainability remains practically absent nowadays in many high school and university chemistry curricula all over the world. Behind this lack of attention to the current situation of planetary emergency, there are several obstacles that we analyse in this paper. We firstly discuss an extended conception of "pure Chemistry" -object of chemists' research and teaching- the object of which would just be to increase knowledge: moral problems should only appear in connection to the use of the applications of science by, generally, nonscientists. This belief that genuine scientific activity lies beyond the reach of moral judgment is logically transferred to teaching, voluntarily limited to the transmission of the corpus of knowledge. Consequently, the challenges of sustainable development, with so many social implications, are put aside. After questioning this and other obstacles, we develop the possible contribution of chemistry and chemical education to the construction of a sustainable future, in accordance with the goals of the International Year of Chemistry.
\end{abstract}

Keywords: Philosophy of Chemistry; Chemistry and society; Ethics and Chemistry; Planetary Emergency; Sustainability; Chemical Education; Education for Sustainability. 


\section{Introduction}

In December 2008 the United Nations, at its 63rd general assembly, adopted a resolution proclaiming 2011 as the International Year of Chemistry and placing UNESCO and the International Union of Pure and Applied Chemistry (IUPAC) at the helm of the event. On this occasion, Koïchiro Matsuura, Director-General of UNESCO, stressed the importance of raising public awareness about chemistry with regard to the challenges of sustainable development. More specifically, in regard to education, the IUPAC and UNESCO envisage that "the International Year of Chemistry will make a strong educational contribution toward the goals of the UN Decade of Education for Sustainable Development".

This stress on education seems really necessary because chemistry (and any other science) teachers' perceptions of the state of the world show a serious lack of understanding (Gil-Pérez et al. 2003; Marques et al. 2008), while education for sustainability has been practically absent in most high school and university curricula all over the world until quite recently. It is true that many university texts on General Chemistry began, at the end of the eighties, to make reference to several environmental problems such as acid rain, smog, depletion of the ozone layer, lead poisoning, radioactive waste, or global warming (Atkins 1989; Chang 1991; Kotz and Purcel 1991); and the same happened in many high school Chemistry texts. But in general these references are isolated and incidental. Even in a more recent book promoted by the American Chemical Society (2004), the problematic of sustainability is completely absent. This absence is even more worrying in the last Handbook of Research on Science Education (Abell and Lederman 2007). In chapter 22 of this book, entitled "Teaching and Learning the many faces of Chemistry" (De Jong and Taber 2007), there is nothing about education for sustainability, not even in the section "A look to the near future of Chemical Education". The same happens in the chapters 20, 21 and 23, devoted respectively to high school Biology curricula (Lazarowitz 2007), the teaching of Physics (Duit, Niedderer and Schecker 2007), and learning Earth Sciences (Orion and Ault 2007). Only chapter 24 of the Handbook, "Environmental Education" (Hart 2007), speaks of education for sustainable development in schools, but this does not justify the absence of education for sustainability when speaking, for instance, of chemical education, because "although those not directly involved in environmental education may think of it as a formal subject to be taught as a distinct part of the curriculum, it may better be regarded as a competence, as a permeating quality extending from personal and social values and emerging as ways of thinking, acting, or being" (Hart 2007, page 690). 
Behind this lack of attention to the current situation of "planetary emergency" (Bybee 1991) -which very particularly affects the teaching of Chemistry, the subject of this paperthere are several obstacles that we intend to analyse here.

We shall firstly discuss a widespread conception of "pure Chemistry" -objective of chemists' research and teaching- to be distinguished from its applications, which "are not chemists' responsibility". After this crucial philosophical discussion about chemists' responsibility, we will contemplate other obstacles, such as the lack of tradition of research and teaching of global problems such as those characterising the situation of planetary emergency.

Finally, we will analyse what can be done to incorporate education for sustainability into Chemistry curricula and teaching.

\section{Chemical Education as an ethically laden activity}

For many scientists and also common citizens the objective of doing and teaching Chemistry or any other science is to increase knowledge and has nothing to do with ethics: moral problems should only appear in connection to the use of the applications of science by, generally, nonscientists (Del Re 2001). This belief that genuine scientific activity lies beyond the reach of moral judgment is logically transferred to teaching, voluntarily limited to the transmission of the corpus of knowledge. No wonder "the challenges of sustainable development", with so many social implications, are put aside.

But, may we accept this belief in the neutrality of science and science teaching? Let us consider, for instance, chemical synthesis: its scientific products are new substances that change our material world, for the benefit or to the detriment of humans and other living beings (Schummer 2001) interfering with the delicate equilibrium of nature. Environmental pollution or ozone layer depletion are not just 'side-effects' of chemical products: we chemists are co-responsible for all possible damage caused by our creations (without forgetting that others are also responsible). In fact, the production of scientific knowledge cannot be separated from its application and neither of the two can be divorced from the ethical responsibilities of scientists or engineers (Gorokhov 2010). Even chemists aiming to improve the material conditions of life for the benefit of humanity should be aware of the possible negative effects of their products.

In other words, we cannot accept that doing science is good just insofar as it increases our knowledge: the pursuit of pure knowledge can have an impact on nature and society and thus cannot be considered morally neutral; in research too, a scientist has to respect values, and 
knowledge is not the only value, nor does it justify the means used to attain it (Del Re 2001). Therefore, holding chemists, and everybody else, responsible to humanity for the consequences of their actions is, in the strongest possible sense, justified (Schummer 2001).

This responsibility begins with the choice of research problems (Kovac 2001): chemists are co-responsible for research aimed at satisfying private interests in the short term ("toys for the rich") instead of deeper human necessities such as putting an end to hunger or environmental degradation and contributing to the construction of a sustainable future (Lubchenco 1998).

To sum up, Chemical research is an ethically laden activity that has to respect values; and the same has to be said of Chemical education. But a "value", in essence, is just a general particularly desirable goal (Del Re 2001) and the primary value is, or should be, the welfare of humanity, including all present and future human beings (Schummer 2001). That is to say, the primary value to respect is sustainability. Therefore, we must salute the decision of the IUPAC and UNESCO to raise "public awareness about chemistry with regard to the challenges of sustainable development" as a principal aim to enhance during the International Year of Chemistry. In order to do so, it is necessary to overcome prejudices that obscure the issue of ethics in chemistry (Lazlo 2001), as the neutrality of chemical research and teaching we have discussed here. But there are other obstacles that may prevent chemistry teachers from addressing the situation of planetary emergency. We will now summarise them.

\section{What obstacles could prevent chemistry teachers from addressing the situation of planetary emergency and how can we overcome them?}

We have just analysed the myth of the neutrality of chemistry research and its consequence in limiting teaching to the transmission of a neutral corpus of knowledge. A new and serious obstacle for the incorporation of sustainability into the chemistry curricula, teaching and educational research lies in the lack of tradition of education as regards approaching global problems which demand systemic treatment (Morin 1999). This is a serious obstacle, because problems such as environmental pollution, depletion of natural resources, ecosystem degradation and desertification, disordered and speculative urbanisation, economic growth guided by private short term interests, demographic explosion on a limited planet, overconsumption in "developed" societies and dominant groups in any society (as if the Earth's resources were infinite), huge social inequalities, etc., are intimately related and cannot be solved separately (Diamond 2005). If we wish to correctly understand the current planetary emergency and how we should act, we need to construct a global picture of the state of Planet Earth and to study the possible causes and remedies thoroughly. Table 1 summarises the 
ensemble of related problems, causes and challenges which characterise the state of the world (Gil-Pérez et al. 2003; Marques et al. 2008).

Table1. Problems and challenges which characterise the situation of planetary emergency

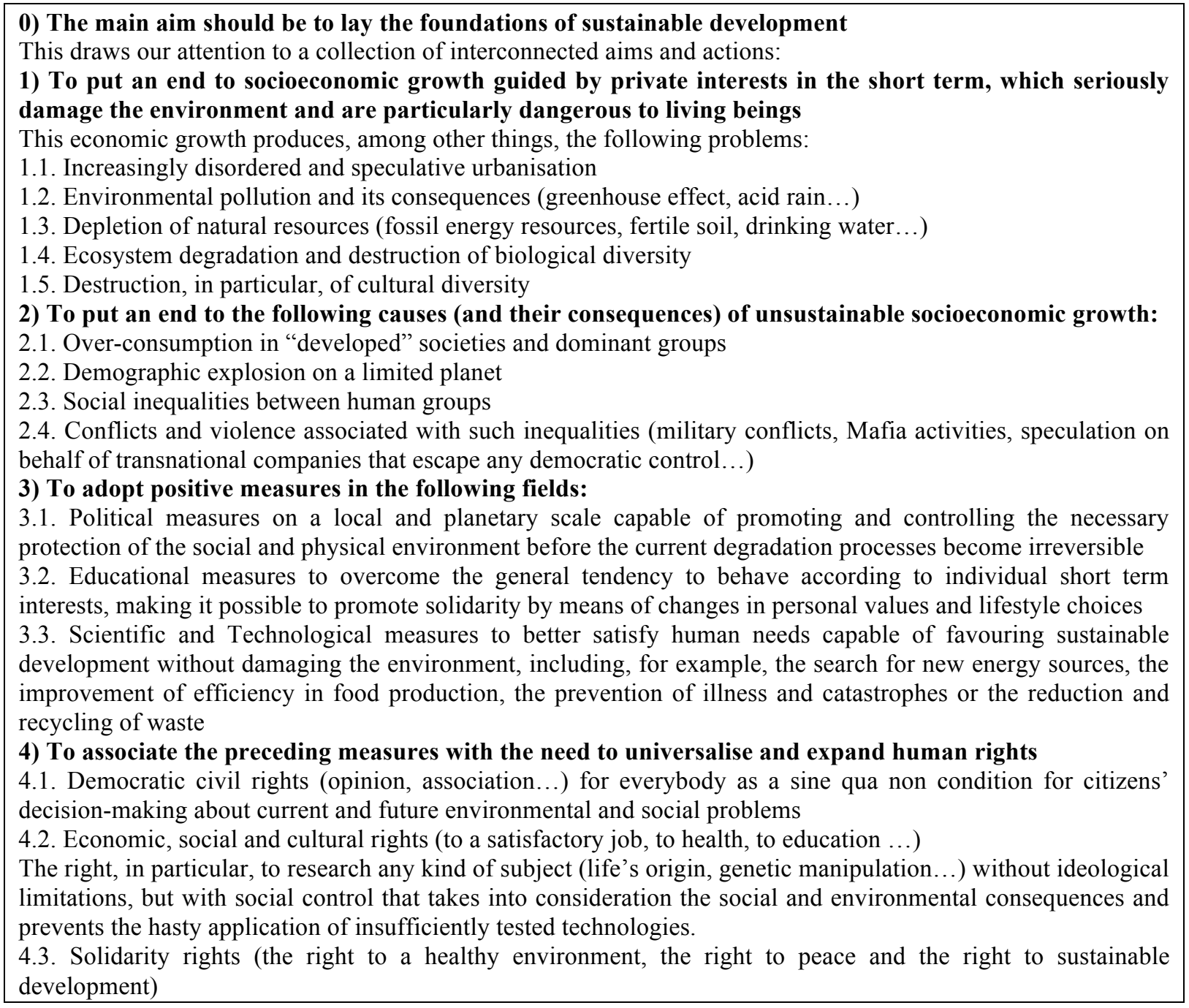

Although each problem is of particular importance and deserves individual attention, none of them can be understood or addressed without taking into account the whole ensemble (World Commission on Environment and Development 1987; Tilbury 1995; Mayor Zaragoza 2000; Vilches and Gil 2003; Diamond 2005; Vilches and Gil 2011). It is not enough, for instance, to speak of acid rain in a chapter, of the global warming trend caused by the 'greenhouse effect' in another and so on: it is necessary to establish the connection between these and other problems and to show how they enhance each other giving rise to a situation of planetary emergency (Bybee 1991; Vilches and Gil 2003; Duarte 2006). That means that the treatment must become interdisciplinary, because the situation cannot be studied inside the limits of chemistry or any other specific subject. We cannot understand, for instance, the reasons of the increment of the greenhouse effect, or how to stop it, without taking into 
account the demographic explosion or the characteristics of current socioeconomic growth. For this reason we need to proceed to a global discussion of the situation, not limited to the problems exclusively related to chemistry. In other words, we have to analyse the Earth's situation globally, keeping in mind the necessity of holistic approaches.

In order to favour a collective reflection of this kind, we have used a programme of activities in many courses and workshops (Gil-Pérez et al. 2003), beginning with an activity such as this: "List the problems and challenges which, in your opinion, humankind will have to face in the near future in order to construct a view as complete and correct as possible of the current situation and of the measures that should be taken". We may contextualise this approach in a chemical curriculum: for instance, when studying chemical synthesis, we can pose students a general question such as "What problems and challenges can be associated to chemical synthesis?" and demand "a collective effort to elicit all possible problems, because given their close connection, ignoring of any of them may hinder an effective treatment of the ensemble".

When we have proposed this task to students (and also to teachers in training and in service), the debate enriches individual visions and although each team continues to express reductive and rather incomplete views, the ensemble of contributions usually covers a great part of the aspects studied by experts (Gil-Pérez et al. 2003; Marques 2008). In fact, this activity allows students to collectively elicit the ensemble of problems and desirable actions we have synthesised in Table 1; and the same result is obtained if a similar question is posed when studying energy resources, etc.

After this initial reflection, we propose successive activities aimed at favouring discussion in small groups of each of the problems and challenges listed. This is followed by a general inter-group discussion and a comparison with experts' points of view. For instance, as the most common problem signalled when we reflect on the world situation is environmental pollution and its consequences, we propose: "Explore more deeply the problem of pollution, listing its different forms and their consequences".

Among the forms of pollution most frequently mentioned are the "chemical soup" (with hundreds of toxic substances present in oil products, pesticides, fertilisers...), radioactive waste, heavy metals and non-biodegradable plastic; and among the consequences, teams refer to acid rain, the destruction of the ozone layer, the green-house effect, etc. These are problems usually addressed in different chapters of recent Chemistry textbooks, but they appear now, together with many other forms of pollution usually less frequently mentioned, but equally dangerous, as part of a global consideration of pollution caused by human activities: reference 
is made to acoustic pollution (due to industrial activity, transport and inadequate urban planning, which can cause serious physical and psychological damage), light pollution (which affects the vital processes of living beings), or space pollution with so-called "space waste" (the consequences of which may prove to be serious to the communication network which has converted our planet into a global village)... without forgetting that the most polluting human activities are those associated to war. Chemistry is present in many of these activities: in the production of weapons, for instance; but also in the methods for eliminating polluting substances, cleaning soils and purifying air and water sources (Anastas and Warner 1998; Lancaster 2010; http://www.greenchemistrynetwork.org/). This offers us many occasions to discuss the responsibility of Chemists and to make founded decisions, overcoming the myth of the neutrality of science we have presented in section 2 .

On the other hand, some of the consequences of pollution appear related to the destruction of natural resources. Thus, when acid rain is mentioned, reference is made to the destruction of forests. This is an example of a close connection between different problems and allows us to continue to the discussion of natural resource depletion, also associated to a disordered and speculative urbanisation process, to over-consumption in "developed" societies, and to economic growth guided by private interests in the short term that externalises its socioenvironmental consequences.

As we can see, this holistic treatment makes it possible to understand the close connection between the different problems, as well as their "glocal" (simultaneously local and global) repercussions, overcoming the "natural" tendency towards local and isolated treatments and causal reductionism present in many disciplinary treatments.

This holistic discussion allows us to elicit and combat other traditions, such as the consideration of our planet as immense and limitless, which implies that human activities would have only local effects (Fien 1995). In fact, until the second half of the $20^{\text {th }}$ Century, while the earth's population was much smaller than nowadays and technological development had not globalised the planet, the effects of human activities remained locally compartmentalised. However, these compartments have begun to dissolve over the last few decades and many problems (the increment of the greenhouse effect, ozone layer depletion, biodiversity loss, social inequalities, migrations...) have acquired a global dimension and the state of the planet has thus become subject to growing concern in many research fields (Leakey and Lewin 1996; Colborn, Myers and Dumanoski 1997; Anastas and Warner 1998; Lubchenco 1998; Broswimmer 2002; Diamond 2005; Worm et al. 2006; Sachs 2008; Rifkin 2009), and, of course, in science education (Bybee 1991; Fien 1995; Tilbury 2005; Vilches 
and Gil 2003; Mueller 2009) and, more particularly, in chemical education (Moore 2008; Garritz 2009; Vilches and Gil-Pérez 2011).

Another deep-rooted tradition that hinders global approaches to the planetary emergency is the defence of "ourselves" (our family, our clan, our ethnic group, our country, our species...) against "the others", seen as enemies to defeat, following a "them or us" strategy. This results in limiting the attention paid to "our" problems, without considering the consequences for others or future generations. We have to understand that a sustainable future is incompatible with simplistic and Manichean "explanations" that attribute any difficulty to "foreign enemies", and also with the promotion of competitiveness, understood as a contest to achieve something at the expense of others who are pursuing the same objective (Vilches and Gil 2003; Sachs 2008).

We must also take into account certain ideological and religious barriers that make it difficult to comprehend the seriousness of problems such as the demographic explosion and the need to promote responsible family planning.

One marked obstacle stems from the tendency to consider that individual actions have only negligible effects on huge problems such as resource depletion or environmental degradation. But it is easy to demonstrate (very simple calculations are needed) that although, for instance, an individual can only save a very small quantity of energy or materials, when these quantities are multiplied by millions of people, the amount that can be saved becomes quite large, with the consequent reduction in environmental pollution and degradation. In fact, the ensemble of individual actions has, in many cases, a larger effect than industry as a whole. This is what happens, for instance, with the increment of the greenhouse effect: personal cars produce more $\mathrm{CO}_{2}$ than industries... despite only a fifth of the human population having access to them (Vilches and Gil 2003).

We are not denying the fact that those who impose a certain model of development aimed at satisfying private interests, regardless of what may happen to others or to the future, have a greater responsibility. But it is necessary to avoid simplistic explanations, more interested in searching for culprits than in understanding the causes and possible solutions. What we need is a sound understanding of the situation to be able to participate in well founded decisionmaking.

We need to analyse these and other barriers and pseudo-explanations that hinder the treatment of the situation of planetary emergency. However, maybe one of the most serious difficulties derives from giving more attention to problems than to the possible solutions: merely studying the problems provokes at best indignation and at worst despair (Hicks and 
Holden 1995; Arjonilla and Garritz 2007). It is also necessary to study the possible solutions to the planetary crisis described, to explore alternative approaches and to participate in actions aimed at favouring a sustainable future. In this sense, the difficulty of understanding the meaning of sustainability becomes another important obstacle.

The concept of sustainability emerges negatively, as a result of the analysis of the state of the world that displays an unsustainable situation of planetary emergency (Bybee 1991) that seriously menaces the future of humankind. "A threatened future" is, precisely, the title of the first chapter of Our Common Future, the report compiled by the World Commission on Environment and Development (WCED 1987), where we find one of the first attempts to introduce the concept of sustainability through the definition of Sustainable Development as a development that meets the needs of the present generation without compromising the ability of future generations to meet their own needs.

This classical definition from the WCED has obtained widespread consensus, although sometimes this consensus is purely formal and hides serious misunderstandings. It is necessary, for this reason, to delve deeper into the meaning of the concept of sustainability that, as Bybee (1991) affirms, constitutes the central unifying idea society most needs at this point in human history.

One initial criticism of the many that the WCED definition has received is that sustainability just expresses a common sense idea, more or less explicitly present in many primitive cultures: that of preserving our resources for our descendants.

This criticism has to be rejected and it must be made clear that sustainability is an absolutely new concept: it implies accepting that the Earth is not as large and limitless as we believed and cannot indefinitely bear the effects of many human predator activities. This knowledge about the unsustainability of current socioeconomic growth is recent and has been a real surprise even to experts (Meadows et al. 1972 and 1992).

This knowledge is also new in another and even deeper sense: sustainability has been understood to be only possible on a planetary scale and demands the consideration of the ensemble of Earth's interconnected problems: a sustainable city or country has no meaning, because problems have a planetary dimension: there are no borders for pollution or for ocean degradation. A country or a city can (and must!) contribute to sustainability, but cannot aspire to be sustainable by itself, regardless of the rest of the world. As Brazilian theologist Leonardo Boff says, this time there will be no Noah's Ark to preserve some human beings: this time salvation will be for all of us or for none of us. People will not be "chosen". 
Sustainability undoubtedly implies a new knowledge that expands with great difficulty, because the signs of degradation have not been sufficiently visible until very recently and because, in certain parts of the world, human beings have notoriously improved their quality of life. Subordination of nature to the necessities and wishes of human beings has always been considered as a distinctive sign of advanced societies, explains the former General Director of UNESCO Mayor Zaragoza (2000) in The World Ahead: Our Future on the Making. In fact, it was not even seen as subordination: nature was considered practically unlimited and people could focus their attention on their own necessities without bothering about environmental consequences. Experts' alarm and international studies (Meadows et al. 1972; Worldwatch Institute 1984-2011; World Commission on Environment and Development 1987; Diamond 2005; Sachs 2008) are abundant, but most citizens are not yet aware, not even technoscientific, economical or political leaders... or educators.

We have to recognise the fact that the recent preoccupation for the preservation of our planet's conditions of life constitutes an authentic and difficult cultural revolution (Mayor Zaragoza 2000): emerging in just one or two generations, this cultural, scientific and social metamorphosis breaks a long tradition of indifference towards the environment. Nevertheless, it is not a question of considering development and environment as contradictory (the first "attacking" the second and the second "limiting" the first), but of recognising that both are intimately associated and cannot be treated separately: after the Copernican Revolution that unified Heaven and Earth, after the Theory of Evolution, that shows the relationship between humankind and the rest of living beings, we are presently witnessing the integration of environment and development into a new paradigm of ecological or green economy, based on the idea of sustainable development (Vilches and Gil 2003; Sachs 2008; Rifkin 2009).

At this point we find another quite serious obstacle to the acceptance of the new paradigm: considering that the expression "sustainable development" is an oxymoron is to say that it associates two contradictory terms and that the new concept is a "green washing" stratagem of supporters of limitless economical growth that intends to present it as compatible with ecological sustainability (Girault and Sauvé 2008). Nonetheless, the idea of sustainable development explicitly rejects the identification of development and growth. As Daly (1991) points out, we have to distinguish between growth and development: growth is a quantitative increase on a physical scale while development is a qualitative improvement or the unfolding of potentialities. In view of the fact that the human economy is a subsystem of a global ecosystem which cannot grow, it is clear that economic growth is not sustainable over a long period. In other words, growth cannot continue indefinitely in a limited world, but 
development is possible. Possible and necessary, because the current ways of life must undergo profound qualitative changes, both for those who live precariously (the majority) and for the minority that exercise predator-like over-consumption. These necessary qualitative changes constitute development (not growth) that is naturally necessary to design carefully, to avoid ambiguities and inappropriate uses of the expression "sustainable development" (Vilches, Gil and Cañal 2010).

Sustainability can play, following these clarifications, the central unifying role that Bybee (1991) attributes to this concept. This central unifying role is based on the global study of problems, their causes and the adoption of suitable measures, which need to be contemplated globally, overcoming any simplistic expectations of finding simple solutions to the connected problems humanity has to face nowadays and in the near future. It is essential to pay attention to these obstacles in order to overcome the poor response to the United Nations calls to contribute to citizens' awareness and understanding of the state of the world.

Bearing these obstacles in mind, we are convinced that if we promote a global discussion in some depth, based on founded documentation, we may obtain more correct perceptions and more favourable attitudes from teachers for the inclusion of this issue in education; an inclusion that, moreover, contributes to more relevant curricula in subjects such as chemistry, and favours students' interest and learning. This can be, attending to our experience (GilPérez et al. 2003; Marques et al. 2008), an effective way of making clear that there is a situation of planetary emergency and that each of us has the ethical commitment and the privilege of contributing towards reverting it.

\section{How can we contribute to the Construction of a Sustainable Future?}

One of the main obstacles to the incorporation of students and citizens to the construction of a sustainable future stems from paying more attention to the problems than to the possible solutions (Hicks and Holden 1995). It is, thus, particularly necessary that chemical education (as well as education in any other domain) facilitates the exploration of alternative approaches and gives the opportunity to participate in actions aimed at favouring a sustainable future. With this aim in mind, we propose a discussion in our courses and workshops about what measures could be adopted to confront the situation of planetary emergency.

This discussion, with the help of well-founded information, makes it understood that it is possible to reverse the current process of planetary degradation, being necessary to implement together, and as soon as possible, an ensemble of techno-scientific, educational and political measures. It is this understanding that encourages the necessary knowledge-based activism of 
students and teachers, and very particularly, a positive response to the United Nations call to incorporate education for sustainability into our teaching and research as a collective ethical commitment. We shall discuss this ensemble of measures in some detail.

\subsection{Techno-scientific measures}

There is general agreement over the need for technologies that favour sustainable development (Daly 1991; Lubchenco 1998; Flavin and Dunn 1999; Sachs 2008; Rifkin 2009), including a strong development of "Green Chemistry" (Anastas and Warner 1998; Colonna, 2005; Lancaster 2010). The proposed measures range from the search for new and clean energy resources (Menéndez and Moliner 2011), the improvement of efficiency in food production (Worldwatch Institute 2011), the prevention of illnesses and catastrophes or the reduction and recycling of waste to the attainment of responsible family planning (Vilches and Gil 2003, chapter 12).

However, it is necessary to carefully analyse the technologies conceived, because an apparent solution might well generate more serious problems than it solves. Daly (1991) suggests two principles that must characterise technology in order to be compatible with sustainable development:

- The rate at which resources are gathered must not exceed regeneration rates (or, for resources that are not renewable, the creation of renewable substitutes).

- Waste production rates must be lower than the assimilation capacities of the planet's ecosystems.

Additionally, Daly insists on the fact that we are moving from an economy of an empty world (where technology was the limiting factor for taking advantage of the exploitation of natural resources) towards an economy of a full world, where natural capital will increasingly become the limiting factor. This imposes a third principle or characteristic:

- The aim of technology for sustainable development must be to increase the efficiency of resources, rather than raise their extraction rate. This means, for instance, that we need to produce more efficient lamps instead of constructing more electrical power stations.

These essentially technical criteria must be accompanied by others of an ethical nature (Vilches and Gil 2003, chapter 12) such as:

- Priority must be given to techno-scientific developments oriented towards satisfying basic needs and reducing social inequalities (Kovac 2001). 
- A Principle of Precaution has to be systematically applied to avoid the hasty application of a certain technology when possible negative effects have not been sufficiently discarded by research (Garritz 2009). Chemical development has given numerous examples of the consequences of this hasty application of innovations not sufficiently tested (Vilches and Gil-Pérez 2011).

These two principles are oriented towards overcoming the private interests in the short term that have usually characterised techno-scientific development, and they proceed to question the widespread and erroneous idea that the solution to the serious problems humanity has to face today depends solely on a better knowledge and on more advanced technologies: options and dilemmas are essentially matters of ethics (Aikenhead 1985; Tilbury 1995; Delors 1996; Mayor Zaragoza 2000; Del Re 2001; Kovac 2001) and demand the consideration of educational and political measures.

\subsection{Educational measures}

The importance given by experts to the role of education is shown clearly by the numerous appeals by the United Nations and other international institutions to educators of any subject and level, both formal (school curricula) and informal (press, museums...) and, particularly, in the proclamation of the Decade of Education for a Sustainable Future (2005-2014).

The educational measures proposed to contribute to a sustainable society emphasize global analyses and the search for global and joint solutions (Delors 1996; Morin 1999; Vilches and Gil 2003; Diamond 2005; Vilches and Gil-Pérez 2011). Such measures are aimed at overcoming the usual tendency to satisfy individual interests in the short term (or to follow habits that correspond to an 'empty' world of isolated compartments). We need education to contribute to a correct perception of the state of the world and to prepare citizens for decisionmaking (Aikenhead 1985; Kovac 2001), generating responsible attitudes and behaviours (Bybee 1991; Fien 1995; Tilbury 1995; Mayor Zaragoza 2000; Rifkin 2009; Worldwatch Institute 2010) oriented towards the achievement of culturally plural and physically sustainable development.

Questions like "What energy policy should be promoted?" or "What role should be given to genetic engineering in the food industry?" and "What controls on GM food production should be introduced?" demand informed decision-making and the adoption of suitable policies. We need education to promote responsible behaviour, not just favourable opinions and attitudes (Vilches and Gil 2003, chapter 13). 
It is necessary for such education to promote the analysis of conceptions that are presented as "obvious" and "unquestionable" without alternatives, thus obstructing the possibility of making choices. This is particularly the case with competitiveness. Almost everybody speaks of competitiveness as something that is absolutely necessary, without realising that this type of behaviour is incompatible with the aim of sustainable development, because the success of one person or group in, let's say, a commercial competition, implies the failure of others... whose future is not taken into account. This contradicts, we insist, the characteristics of sustainable development, which must necessarily be global and embrace the whole planet. Instead of promoting competitiveness, we need education to help students and teachers to analyse the efficiency of our actions from a global viewpoint, taking into account its repercussions in the short, medium and long term, both for ourselves and for the whole of humanity. We need education to help to transform the current competitive economic globalisation into a democratic and sustainable project (Sachs 2008) that enhances the richness of biological and cultural diversity.

These educational aims need to be incorporated into an appropriate educational framework: research and innovation are needed to conceive and implement the incorporation of education for sustainability in the various educational activities, both formal and informal, including teacher training.

To finish with these general considerations on the role of education -and, more particularly, chemical education- in promoting sustainability, it is necessary to stress that individual contributions can and must go beyond the private domain and be extended to professional, social and political activities. Citizens can support, for instance, nongovernmental organisations and political parties that promote solidarity and environmental protection; they can also demand positive action on behalf of public institutions (town councils, parliaments). Furthermore, it is particularly necessary for these individual and collective citizen actions to avoid just local or partial approaches and contemplate many-sided environmental issues (pollution, resource depletion...), and other related problems, such as social inequalities and conflicts, from a planetary perspective. The ecologist slogan "to think globally and to act locally" has its limitations and has given rise to the concept of glocality: we now know that it is also necessary to act globally as well (O'Connor 1992), by adopting political measures on a planetary scale, capable of avoiding the imposition of individual interests and values that are harmful to other people or for future generations. We comment on these in the next section. 


\subsection{Political measures}

To begin with, we have to remember that we are facing problems of a planetary dimension that cannot be tackled with just local approaches: political measures on a local, regional and planetary scale are required.

The discussion about the political measures that could promote sustainable development usually produces heated debates and demands careful analysis. The adoption of planetary political measures is contemplated by most science teachers and citizens with scepticism and certain reluctance, because, as we have already commented, there is a deeply rooted prejudice in the neutrality of science and science teaching (Del Re 2001), as well as a strong tendency, to limit our attention to "ourselves" (our country...) and to forget "the others" or to even look upon them as a threat. Nevertheless, climate change, which knows no borders, reminds us that we are living - for the first time in human history - in an interconnected civilisation that embraces the whole planet. We can therefore understand the absolute necessity, also for the first time in human history, for political integration to put the environment, as the common substratum of life, ahead of the individual interests of any country, region or transnational enterprise.

We might think that the danger of employing only local approaches is disappearing because of the current dizzying process of economic globalisation. Paradoxically, this process is not global at all when it concerns the survival of life on our planet. In spite of so much talk about globalisation, most approaches remain partial, ignoring the environmental consequences of current economic growth; on the contrary, economic globalisation irresistibly pushes to displace production centres towards countries where ecological norms and labour rights are less restrictive (Sachs 2008).

Economic globalisation thus appears to be serving the short term interests of a minority. For this reason, planetary norms are necessary in order to avoid the general degradation of the environment and its tremendous economic cost, which has only just begun to be evaluated (Constanza et al. 1997; Sachs 2008). In this sense, political integration on a planetary scale is deemed absolutely necessary and urgent; this integration must be capable of promoting and controlling the measures to protect our social and physical environments, before the degradation process becomes irreversible (Duarte 2006).

In short, a new world order is required, based on cooperation and solidarity, with institutions capable of avoiding the imposition of short-sighted individual interests, harmful to other people, to future generations and even harmful to the future of the predators' themselves 
(Renner 1999; Giddens 1999; Sen 1999; Vilches and Gil 2003, chapter 14; Sachs 2008; Worldwatch Institute 2008 and 2010; Rifkin 2009).

However, this planetary political integration, that our survival seems to depend on, also generates the fear of cultural homogenisation, which is already in progress: that is to say, the fear of cultural impoverishment. But this destruction of cultures cannot be attributed to a process of political integration which has not yet occurred. It is just another consequence of purely commercial integration. A democratic order on a planetary scale could contemplate the protection of the environment and the defence of biological and cultural diversity, promoting intercultural exchanges to take advantage of this diversity (Vilches and Gil 2003, chapter 14; Maaluf 1998 and 2009).

A fully democratic worldwide political integration constitutes, therefore, a prerequisite to:

- Stop the current physical and cultural degradation of the planet;

- Put an end to unsustainable social inequalities;

- Stop unilateralist actions, world terrorism and trafficking of arms, drugs, capital and persons.

- Advance towards sustainability.

Our survival, our basic right to life, depends on it; to the extent that the hypothesis of an imminent "Sixth Global Extinction of Species", with humankind being the main agent and victim, has been seriously advanced and justified (Leakey and Lewin 1996). This is connected to the fundamental question of human rights, which is closely linked, as we will attempt to demonstrate, to the attainment of sustainability. The next section is devoted to clarifying this relationship.

\subsection{Sustainability and human rights}

It may seem strange to establish such a direct relationship between human rights and sustainability. For this reason, we shall try to clarify what is understood nowadays by human rights -a concept that has grown and now contemplates three "generations" of rights (Vercher 1998; Vilches and Gil 2003, chapter 15) - and how they are related to the attainment of a sustainable future.

We can refer, firstly, to democratic civil rights (opinion, association...) for everybody, without social, ethnic or gender limitations. They constitute a sine qua non condition for citizens' decision-making about current and future environmental and social problems. They are known nowadays as "first generation human rights", because they were the first rights to 
be demanded and obtained (not without conflicts) in a growing number of countries. In this respect, we must not forget that the 'Droits de l'Homme' from the French Revolution (to quote a well known example) excluded women explicitly; women only achieved the right to vote in France after the Second World War. Nor must we forget that such basic rights are nowadays systematically violated every day in many countries.

Amartya Sen (1999) concluded that the expansion of liberties is, at the same time, a basic aim of social development and its principal instrument in order to make sustainability possible. But a sustainable future demands the recognition of other rights, besides these civil rights. We are referring to economic, social and cultural rights or "second generation human rights" (United Nations Development Programme 2000), such as the universal right to a satisfying job, adequate dwelling, appropriate nourishment, education, health, family planning and free enjoyment of sexuality, etc.

Finally, we refer to third-generation human rights, known as solidarity rights because they tend to preserve the integrity of the whole population (Vercher 1998). They incorporate the right to life in a suitable environment, the right to peace and the right to sustainable development for all people and future generations.

The ensemble of these rights appears to be a requisite (and, at the same time, an objective) of a sustainable society, as they are all interconnected. We cannot expect, for instance, some people not to contribute to the depletion of a fishing bank... when this is their only resource to nourish their family. And we cannot conceive, to give another example, the interruption of the demographic explosion without the recognition of the right to family planning and free enjoyment of sexuality... and this is also connected to the right to education: as Mayor Zaragoza (2000) states, only education for all can reduce the continuous growth of the population in any religious or ideological context.

In summary, achieving sustainable development is synonymous with universalising human rights in the broadest sense of the term (Vilches and Gil 2003, chapter 15). This requires:

- Orientating scientific-technological development -such as green chemistry (Anastas and Warner 1998; Colonna 2005; Lancaster 2010)- towards the attainment of technologies that favour sustainable development;

- Promoting education -including chemical education (Moore 2008; Garritz 2009)- that is capable of countering the usual tendency to behave according to individual interests in the short term; 
- Attaining international agreements and creating democratic institutions, on a planetary scale, capable of preventing the imposition of private interests that are harmful to other people or future generations (Vilches and Gil 2003, chapter 14).

\section{Promoting the Decade of Education for a Sustainable Future: an ethical commitment}

We have tried to show that chemical education is an ethically laden activity that can and must incorporate sustainability as an essential dimension, responding positively to the call of United Nations to educators of all subjects and levels to contribute to the goals of the Decade of Education for a Sustainable Development, confronting the present situation of planetary emergency that affects human survival.

Indeed, chemistry and chemical education have already begun to contribute to the necessary revolution for sustainability, thanks to the many developments of Green Chemistry and the growing incorporation, in high school and university chemistry curricula, of the ensemble of problems and challenges that we have summarised in Table 1. This incorporation is fully justified because chemistry research and development are clearly associated to these problems and challenges, albeit still insufficient for what we need to promote.

We must be aware that this Decade for a Sustainable Future will be decisive in one sense or another: sadly decisive if we remain entrenched in our routines and short-sighted interests, without recognising the need to revert a degradation process that is constantly sending us unequivocal signals in form of global heating, unnatural catastrophes, loss of biological and cultural diversity, millions of deaths by inanition, dramatic migrations... and a long etcetera; happily decisive if we are capable of generating, right now, a universal and powerful trend for a sustainable future based on cooperation and the adoption of an ensemble of measures such as those we have discussed.

This is the aim that we can and must incorporate into chemical education, as well as into any other subject. We are aware of the difficulties, but must be determined to contribute, as educators, scientists and citizens, to creating the conditions for a sustainable future, which is still possible.

\section{References}

Abell, S.K. \& Lederman N.G. (2007). Handbook of Research on Science Education. New York: Routledge.

Aikenhead, G. S. (1985). Collective Decision Making in the Social Context of Science. Science Education. 69 (4), 453-475. 
American Chemical Society (2004). Chemistry. A Project of the American Chemical Society. New York: Freeman and Company. (Written by an editorial/writing team composed by Bell, J., Branz, S., Bunce, D., Cooper, M., Eubanks, I.D., Eubanks, L.P., Kaesz, H., Morgan, W., Noether, D., Scharberg, M., Silberman, R. \& Wright, E.).

Anastas, J. \& Warner, J. (1998). Green Chemistry: Theory and Practice. Oxford: Oxford University Press.

Arjonilla, E. \& Garritz, A. (2007). Cambio climático. Lo que podemos hacer los educadores. Educación Química, 18 (4), 251-256.

Atkins, P.W. (1989). General Chemistry. New York: Scientific American Books.

Broswimmer, F. J. (2002). Ecocide. A Short History of the Mass Extinction of Species. London: Pluto Press.

Bybee, R.W. (1991). Planet Earth in Crisis: How Should Science Educators Respond? The American Biology Teacher, 53(3), 146-153.

Chang, R. (1991). Chemistry (4th edition). New York: McGraw-Hill.

Colborn, T., Myers, J. P., \& Dumanoski, D. (1997). Our Stolen Future. New York: Dutton.

Colonna, P. (Ed.) (2005). La Chimie Verte. Paris: Technique et Documentation- Lavoisier.

Constanza, R., d'Arge, R., de Groot, R., Farber, S., Grasso, M., Hannon, B., Limburg, K., Naeem, S., O'Neill, R., Paruelo, J., Raskin, R., Sutton, P. \& van den Belt, M. (1997). The Value of the World's Ecosystem Services and Natural Capital. Nature, 387, 253260.

Daly, H. (1991). Steady-State Economics. Washington D.C.: Island Press.

De Jong, O. and Taber, K.S. (2007). Teaching and Learning the many faces of Chemistry. In Abell, S.K. \& Lederman N.G. (Ed.). Handbook of Research on Science Education (Chapter 22). New York: Routledge.

Del Re, J. (2001). Ethics and Science. HYLE. International Journal for Philosophy of Chemistry, 7 (2), 85-102.

Delors, J. (1996). L'Éducation: un Trésor est caché dedans. Paris: Jacob O.

Diamond, J. (2005). Collapse: How Societies Choose to Fail or Succeed. New York: Viking.

Duarte, C. (Ed.) (2006). Cambio Global. Impacto de la actividad humana sobre el sistema Tierra. Madrid: CSIC.

Duit, R., Niedderer, H. and Schecker, H. (2007). Teaching Physics. In Abell, S.K. \& Lederman N.G. (Ed.). Handbook of Research on Science Education (Chapter 21). New York: Routledge.

Fien, J. (1995). Teaching for a Sustainable World: the Environmental and Development Education Project for Teacher Education. Environmental Education Research, 1(1), 21-33.

Flavin, C. \& Dunn, S. (1999). Reinventing the Energy System. In Worldwatch Institute (Ed.), The State of the World 1999. New York: W. W. Norton.

Garritz, A. (2009). Química verde y reducción de riesgos, Educación Química, 20 (4), 394397.

Giddens, A. (1999). Runaway World: How Globalisation is Reshaping Our Lives. London: Profile Books.

Gil-Pérez, D., Vilches, A., Edwards, M., Praia, J., Marques, L. \& Oliveira, T. (2003). A proposal to enrich teachers' perception of the state of the world. First results. Environmental Education Research, 9(1), 67-90.

Girault, Y. \& Sauvé, L. (2008). L'éducation scientifique, l'éducation à l'environnement et l'éducation pour le développement durable. Aster, 46, 7-30.

Gorokhov, V. (2010). Vladimir I. Kurashov: History and Philosophy of Chemistry. HYLE. International Journal for Philosophy of Chemistry, 16(2), 121-125. 
Hart, P. (2007). Environmental Education. In Abell, S.K. \& Lederman N.G. (Ed.). Handbook of Research on Science Education (Chapter 24). New York: Routledge.

Hicks, D. \& Holden, C. (1995). Exploring the Future: a Missing Dimension in Environmental Education. Environmental Education Research, 1(2), 185-193.

Kotz, J.C. \& Purcell, K.F. (1991). Chemistry \& Chemical Reactivity. Philadelphia: Saunders College Publishing.

Kovac, J. (2001). Gifts and Commodities in Chemistry. HYLE. International Journal for Philosophy of Chemistry, 7(2), 141-153.

Lancaster, M. (2010). Green Chemistry. An Introductory Text. Cambridge: RSC Publishing.

Laszlo, P. (2001). Handling Proliferation. HYLE. International Journal for Philosophy of Chemistry, 7(2), (2001), 125-140.

Lazarowitz, R. (2007). High School Biology Curricula: Implementation, Teaching, and Evaluation from the 20th to the 21th Century. In Abell, S.K. \& Lederman N.G. (Ed.). Handbook of Research on Science Education (Chapter 20). New York: Routledge.

Leakey, R. \& Lewin, R. (1996). The Sixth Extinction. Biodiversity and its Survival. London: Weidenfeld and Nicolson.

Lubchenco, J. (1998). Entering the Century of the Environment: A New Social Contract for Science. Science, 279, 491-497.

Maaluf, A. (1998). Les Identités meurtrières. Paris: Grasset.

Maaluf, A. (2009). Le dérèglement du monde. Quand nos civilisations s'épuisent. Paris: Grasset \& Fasquelle.

Marques, L., Vilches, A., Gil- Pérez, D., Praia, J. \& Thompson, D. (2008). The Current Planetary Crisis: a Missing Dimension in Science Education. In Azeteiro, U. M., Gonçalves, F., Pereira, R., Pereira, M.J., Leal-Filho, W. \& Morgado, F. (Ed.), Science and environmental education. Towards the integration of Science Education, Experimental Science Activities and Environmental Education (pp. 25-47). Frankfurt: Peter Lang.

Mayor Zaragoza, F. (2000). The World Ahead: Our Future on the Making. Published in French with the title 'Un Monde Nouveau'. Paris: Editions UNESCO.

Meadows, D.H., Meadows, D.L., Randers, J. \& Behrens W.W. (1972). The Limits to Growth. New York: Universe Books.

Meadows, D.H., Meadows, D.L. \& Randers, J. (1992). Beyond the Limits. White River Junction VT: Chelsea Green Publishing Company.

Menéndez, R. \& Moliner, R. (2011). Energía sin CO . Realidad o utopía. Madrid: CSICCatarata.

Morin, E. (1999). Les sept savoirs nécessaires à l'éducation du futur. Paris : UNESCO.

Moore, J. W. (2008). Editorial: Sustainability. Chemical Education Today. Journal of Chemical Education, 85 (12), 1595.

Mueller, M. (2009). Educational reflections on the "Ecological Crisis": Ecojusticie, Environmentalism and Sustainability. Science \& Education, 18 (8), 1031-1056.

O'Connor, J. (1992). Think Globally, Act Locally? Towards an International Red-Green Movement. Capitalism, Nature, Socialism, 3 (4), 1-7.

Orion, N. \& Ault, C.R., Jr. (2007). Learning Earth Sciences. In Abell, S.K. \& Lederman N.G. (Ed.). Handbook of Research on Science Education (Chapter 23). New York: Routledge.

Renner, M. (1999). Ending Violent Conflict. In Worldwatch Institute (Ed.), The State of the World 1999. New York: W. W. Norton.

Rifkin, J. (2009). The Empathic Civilization. The Race to a Global Consciousness in a World in Crises. Cambridge: Polity Press. 
Sachs, J. D. (2008). Common Wealth: Economics for a Crowded Planet. New Cork: Penguin Press HC.

Schummer, J. (2001). Ethics of Chemical Synthesis. HYLE. International Journal for Philosophy of Chemistry, 7(2), 103-124.

Sen, A. (1999). Development as freedom. New York: A. Knopf, Inc.

Tilbury, D. (1995). Environmental Education for Sustainability: Defining the New Focus of Environmental Education in the 1990s. Environmental Education Research, 1(2), 195212.

United Nations Development Programme (2000). International cooperation at a crossroads: Aid, trade and security in an unequal world. New York: Oxford University Press. http://hdr.undp.org/reports/global/2000/ Accessed 12 August 2011.

Vercher, A. (1998). Derechos Humanos y Medio Ambiente. Claves de razón práctica, 84, 1421.

Vilches, A. \& Gil, D. (2003). Construyamos un futuro sostenible. Diálogos de supervivencia. Madrid: Cambridge University Press.

Vilches, A. \& Gil-Pérez, D. (2011). Papel de la Química y su enseñanza en la construcción de un futuro sostenible. Educación Química, 22 (2), 103-116.

Vilches, A., Gil, D. \& Cañal, P. (2010). Educación para la sostenibilidad y educación ambiental. Investigación en la Escuela, 71, 5-15.

World Commission on Environment and Development (1987). Our Common Future. Oxford: Oxford University Press.

Worldwatch Institute (Ed.) (1984-2011). State of the World. New York: W.W. Norton.

Worldwatch Institute (Ed.) (2008). State of the World 2008: Innovations for a Sustainable Economy. New York: W.W. Norton.

Worldwatch Institute (Ed.) (2010). State of the World 2010: Transforming Cultures: From Consumerism to Sustainability. New York: W.W. Norton.

Worldwatch Institute (Ed.) (2011). State of the World 2011. Innovations that Nourish the Planet. New York: W.W. Norton.

Worm, B., Barbier, E. B., Beaumont, N., Duffy, J. E., Folke, C., Halpern, B. S., Jackson, J. B. C., Lotze, H. K., Micheli, F., Palumbi, S. R., Sala, E., Selkoe, K., Stachowicz, J. J. \& Watson, R. (2006). Impacts of biodiversity loss on ocean ecosystem services, Science, $314,787-790$. 